PRODUCTION

ENGINEERING

ARCHIVES
2016, Vol. 10, No 1, pp 33-37

ISSN 2353-5156

ISSN 2353-7779 (print version)

(online version)

\title{
SWOT analysis application for indications of the strategy action chosen enterprise in the construction sector
}

\author{
Agnieszka Czajkowska ${ }^{1}$ \\ ${ }^{1}$ Kielce University of Technology, al. Tysiąclecia Państwa Polskiego 7, Kielce, Poland, a_czajkowska@o2.pl
}

\begin{abstract}
Only ambitious and success-driven enterprises are able to adapt to continuous changes in closer and further business surroundings. Modern enterprises strive for meeting the customers' expectations and needs. Even the most successful enterprises cannot cease to be competitive and survive only with what they have already achieved. Enterprises have to adopt strategies to ensure continuous development. The aim of the SWOT method, on the one hand, is to indicate the direction the enterprise should take in order to utilize their potential as much as possible and, on the other hand, to realize the shortcomings that should be improved. SWOT analysis helps determine the strategic factors to be used during planning further development of the enterprise. The analysis carried out in the study provided a transparent insight into the factors which depend on the enterprise and those that cannot be affected directly. The recommended mini-mini strategy means that the enterprise is in a good market situation whereas external threats are deepened with internal weaknesses of the enterprise.
\end{abstract}

Key words - SWOT analysis, construction sector, mini-mini strategy

\section{Introduction}

The enterprise analysed in the study operates in the area of comprehensive performance of construction works, comprehensive construction of detached houses, production halls, public utility facilities and demolition of buildings. The SWOT (INGALDI M., ŠKŮRKOVÁ K. 2015) analysis was employed in order to point to the strategy of development in an enterprise that provides construction services. The aim of the SWOT analysis was to indicate the components of the assets which might be regarded as an advantage in the market rivalry with potential competitors, to reveal weaknesses that reduce the strength of the competitive effect and to identify specific competencies of the en- terprise in order to use new opportunities that emerge in the international market (KOSIŃSKAE. 2008). The term SWOT TOWS is often used in the literature (ŻABIŃSKIL. 2000). The term TOWS (LAKE 2005) was obtained through reorganization of the letters in the acronym SWOT and points to the reversion of the order of the analysis. The difference lies in that the SWOT analysis starts from evaluation of internal strengths and weaknesses for which the method for the most effective utilization is attempted to be found, whereas in the TOWS analysis the opportunities and threats are first identified in the enterprise's surroundings and then they are compared to the internal capabilities of using these opportunities and balancing the 
threats. The SWOT acronym derives from the first letters of English words (OBŁÓJK. 2010):

- strengths (S),

- weaknesses $(\mathrm{W})$,

- opportunities (O),

- threats (T).

The aim of the SWOT analysis is to compare the most important factors that characterize the standing of the enterprise and conditions in its surroundings in order to determine the optimal solutions for the activities which the enterprise will be able to start in the market (CZUBAŁAA. et al. 2006).

\section{Material and methods}

The SWOT analysis can be divided into the following steps:

Step 1: Determination of strengths and weaknesses as well as opportunities and threats of the enterprise analysed

One should select key areas of enterprise operation and determine whether they represent strengths or weaknesses of the organization and focus on the most substantial opportunities and threats. The SWOT method offers a method to identify strength, weaknesses, opportunities and threats in the enterprise (ROMANOWSKAM.2004). This analysis is based on the simple pattern of classification: all the factors that have an effect on current and future structures of the enterprise are divided into:

- external with respect to the organization and those having the character of internal determinants,

- the factors which have a negative effect on the organization and those having a positive effect.

Classification of the factors which affect the strategic position of the enterprise (Ingaldi and Jagusiak-Kocik 2013) in the SWOT analysis are presented in Fig. 1.

Step 2: All the characteristics should be described A detailed description of the selected characteristics should be made.

Step 3: The strength of the relationship should be evaluated between strengths/weaknesses and opportunities/threats

The two analyses should be carried out:

- Analysis of the effect of strengths and weaknesses on opportunities and threats.
- Analysis of the effect of opportunities and threats on strengths and weaknesses in the enterprise.

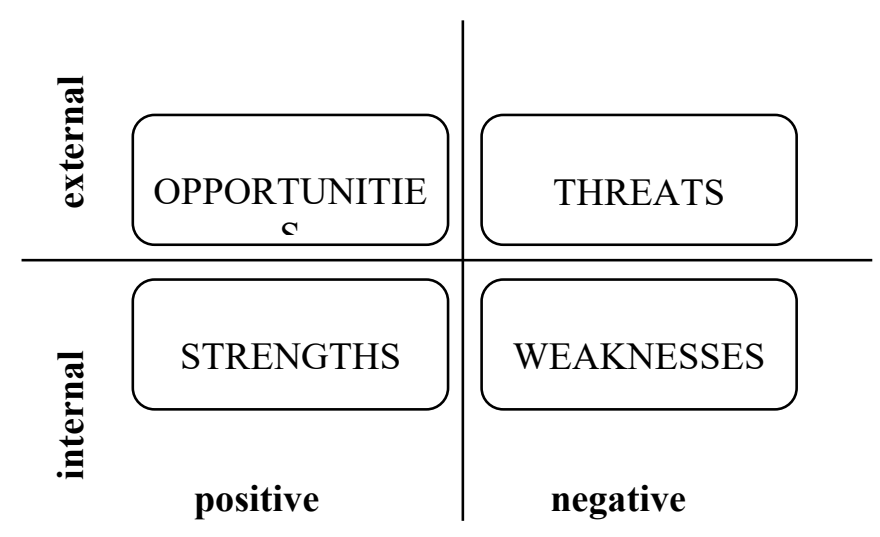

Fig. 1 Factors that affect the strategic position of the enterprise.

Source: OBŁój K. 2001, CZAJKOWsKA A. 2014

Step 4: Based on the results obtained, the matrix of relationships should be prepared between individual factors.

Step 5: Proper strategy should be chosen

There are four strategies of operation discussed in the literature:

- Competitive strategy,

- Aggressive strategy,

- Defensive strategy,

- Conservative strategy.

The strategies of operation (OBŁóJ K. 2001,CZAJKOWSKA A.2014) which can be used are presented in Fig. 2.

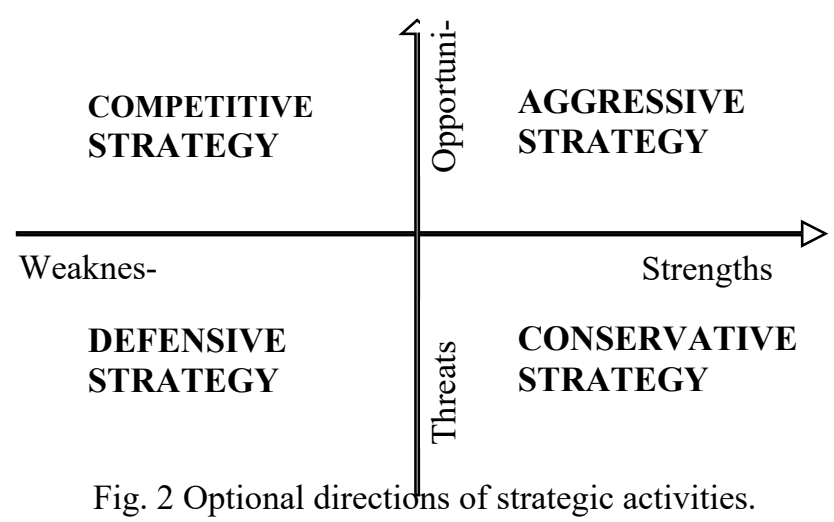

Source:Obłój K. 2001, Czajkowska A. 2014 


\section{Results and discussion}

Potential strengths and weaknesses of the enterprise and opportunities and threats present in the environment are present in Table 1. Another step in the SWOT analysis is to investigate the relationships between weaknesses/strengths and opportunities/threats.

The two analyses should be carried out:
- The effect of opportunities and threats on strengths and weaknesses in the enterprise (Table 2).

- The effect of strengths and weaknesses on opportunities and threats, presented in Table 3.

The effect of strengths and weaknesses on opportunities and threats, presented in Table 2.

Table 1. Internal and external factors identified in the enterprise analysed in the study

\begin{tabular}{|c|c|}
\hline Strengths & Weaknesses \\
\hline $\begin{array}{l}\text { Comprehensiveness of the services } \\
\text { Organizational effectiveness } \\
\text { Educated and experienced managers } \\
\text { High quality of services } \\
\text { Good reputation of the enterprise among customers } \\
\text { Meeting deadlines } \\
\text { Guarantees for the services performed } \\
\text { Experience in the sector }\end{array}$ & $\begin{array}{l}\text { No financial liquidity } \\
\text { No competitive advantage } \\
\text { Problems with new orders } \\
\text { High prices compared to competitors }\end{array}$ \\
\hline Opportunities & Threats \\
\hline $\begin{array}{l}\text { Favorable economic situation in the country } \\
\text { Preferential loans for potential customers } \\
\text { Increase in the demand for new flats } \\
\text { Subsidies from EU funds } \\
\text { Finding new markets } \\
\text { Increasing number of investments }\end{array}$ & $\begin{array}{l}\text { Increased competition in the local market } \\
\text { High unemployment rate } \\
\text { Decline in the incomes among the society } \\
\text { Substantial limitation of construction tax deductions } \\
\text { Freedom of entry of new competitors in the market } \\
\text { Ageing society }\end{array}$ \\
\hline
\end{tabular}

Source: own study

Table 2. SWOT analysis for opportunities and threats / strengths and weaknesses

\begin{tabular}{|c|c|c|c|c|c|c|c|c|c|c|c|c|}
\hline $\begin{array}{l}\text { Strengths/ } \\
\text { Weaknesses }\end{array}$ & 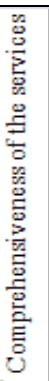 & 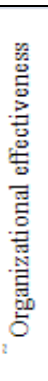 & 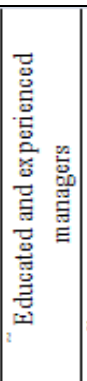 & 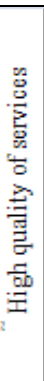 & 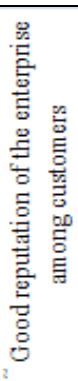 & 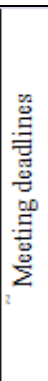 & 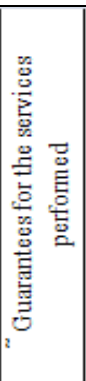 & 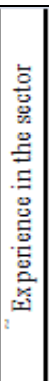 & 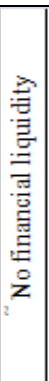 & 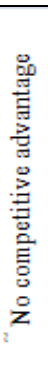 & 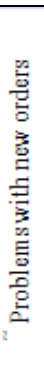 & 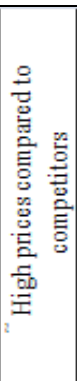 \\
\hline Good economic situation in the country & 0 & 0 & 1 & 1 & 0 & 0 & 0 & 0 & 0 & 0 & 1 & 0 \\
\hline $\begin{array}{l}\text { Preferential loans for potential } \\
\text { customers }\end{array}$ & 0 & 1 & 0 & 0 & 0 & 0 & 0 & 0 & 1 & 0 & 2 & 0 \\
\hline Increase in the demand for new flats & 1 & 0 & 0 & 1 & 0 & 1 & 1 & 0 & 1 & 0 & 1 & 0 \\
\hline Subsidies from EU funds & 0 & 0 & 1 & 2 & 0 & 0 & 0 & 0 & 2 & 1 & 1 & 1 \\
\hline Finding new markets & 0 & 0 & 0 & 0 & 0 & 0 & 0 & 0 & 1 & 1 & 2 & 1 \\
\hline Increasing number of inves & 1 & 0 & 0 & 0 & 0 & 1 & 0 & 0 & 1 & 1 & 2 & 1 \\
\hline $\begin{array}{l}\text { Increased competition in the local } \\
\text { market }\end{array}$ & 0 & 0 & 0 & 1 & 0 & 1 & 1 & 0 & 2 & 2 & 2 & 1 \\
\hline High unemployment rate & 0 & 0 & 0 & 0 & 0 & 0 & 0 & 0 & 2 & 1 & 2 & 0 \\
\hline $\begin{array}{l}\text { Decline in the incomes among the } \\
\text { society }\end{array}$ & 0 & 0 & 0 & 0 & 0 & 0 & 0 & 0 & 1 & 0 & 1 & 0 \\
\hline $\begin{array}{l}\text { Substantial limitation of construction tax } \\
\text { deductions }\end{array}$ & 1 & 0 & 0 & 0 & 0 & 0 & 0 & 0 & 2 & 2 & 2 & 0 \\
\hline $\begin{array}{l}\text { Freedom of entry of new competitors in } \\
\text { the market }\end{array}$ & 1 & 0 & 1 & 1 & 0 & 1 & 1 & 0 & 2 & 1 & 2 & 0 \\
\hline Ageing society & 0 & 0 & 0 & 0 & 0 & 0 & 0 & 0 & 1 & 1 & 2 & 0 \\
\hline
\end{tabular}


The effect of opportunities and threats on strengths and weaknesses in the enterprise, presented in Table 3.

Table 3. SWOT analysis for strengths and weaknesses/ opportunities and threats

\begin{tabular}{|c|c|c|c|c|c|c|c|c|c|c|c|c|}
\hline $\begin{array}{l}\text { Opportunities/ } \\
\text { Threats }\end{array}$ & 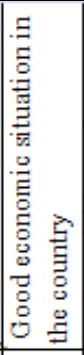 & \begin{tabular}{|l} 
\\
\end{tabular} & 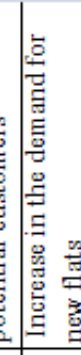 & 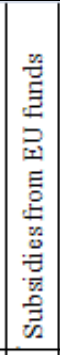 & 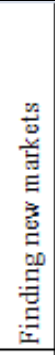 & 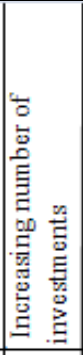 & 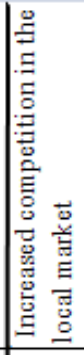 & 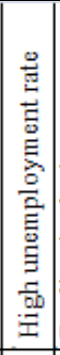 & 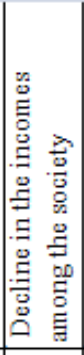 & 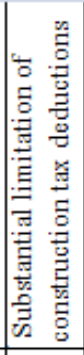 & 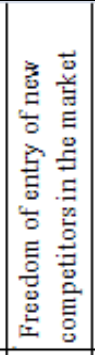 & 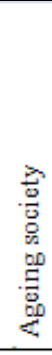 \\
\hline Comprehensiveness of the services & 1 & & 1 & 1 & 1 & 1 & 1 & 0 & 1 & 0 & 1 & 0 \\
\hline Organizational effectiveness & 0 & & 1 & 1 & 1 & 1 & 1 & 0 & 0 & 0 & 1 & 0 \\
\hline Educated and experienced managers & 1 & & 0 & 2 & 2 & 1 & 1 & 0 & 0 & 0 & 1 & 0 \\
\hline High quality of services & 1 & & 1 & 1 & 1 & 1 & 2 & 0 & 1 & 0 & 0 & 0 \\
\hline $\begin{array}{l}\text { Good reputation of the enterprise among } \\
\text { customers }\end{array}$ & 0 & & 0 & 0 & 1 & 1 & 1 & 0 & 0 & 0 & 1 & 0 \\
\hline Meeting deadlines & 0 & & 0 & 0 & 1 & 1 & 1 & 0 & 0 & 0 & 1 & 0 \\
\hline Guarantees for the services performed & 0 & & 0 & 0 & 1 & 1 & 1 & 0 & 0 & 0 & 1 & 0 \\
\hline Experience in the sector & 1 & & 0 & 1 & 1 & 1 & 1 & 0 & 0 & 0 & 1 & 0 \\
\hline No financial liquidity & 1 & & 1 & 1 & 1 & 1 & 2 & 0 & 1 & 0 & 2 & 0 \\
\hline No competitive advantage & 1 & & 0 & 0 & 1 & 0 & 2 & 0 & 0 & 0 & 2 & 0 \\
\hline Problems with new orders & 1 & & 0 & 0 & 1 & 0 & 2 & 2 & 2 & 2 & 2 & 0 \\
\hline High prices compared to competitors & 0 & 0 & 0 & 0 & 1 & 1 & 2 & 1 & 2 & 1 & 1 & 0 \\
\hline
\end{tabular}

Source: own study

Based on the results obtained in the study, a matrix of relationships between individual factors was prepared. The following sums were input to the Table 4:

- strengths (S) and opportunities (O), sum: $\mathrm{SO}+\mathrm{OS}$

- strengths (S) and threats (T), sum: ST+TS,

- weaknesses (W) and opportunities (O), sum: $\mathrm{WO}+\mathrm{OW}$

- weaknesses $(\mathrm{W})$ and threats $(\mathrm{O})$, sum: WT+TW.

Table 4. Comparison of the sums of values

\begin{tabular}{|l|l|}
\hline Factors & Sum \\
\hline Strengths/Opportunities & 50 \\
\hline Strengths/Threats & 27 \\
\hline Weaknesses/Opportunities & 36 \\
\hline Weaknesses/Threats & 55 \\
\hline
\end{tabular}

Source: own study
Results of the collective SWOT/TOWS analysis indicate that the enterprise studied should implement the mini-mini strategy, i.e. defensive strategy. Weaknesses of the enterprise are strongly connected with the threats. Therefore, the enterprise should focus on the activities aimed at survival in the unfavourable environment through minimization of the costs of operation or attempting to merge with the bigger enterprise. However, the assets of the enterprise are too poor to face the challenge of the threats.

\section{Conclusion}

Based on the analysis of the enterprise in the construction sector and the analysis of the environment the enterprise has to operate in, its prospective position was determined and, importantly, the strategy of operation was recommended. Unfortunately, the only strategy that can be recommended is the defensive (mini-mini) strategy. The analysis showed that the 
enterprise studied operates under little advantageous conditions and does not have strengths which could be used for improvement of its standing. The mini-mini strategy consists in reduction of the weaknesses, cost reduction and stopping investments. The enterprise might use the optimistic variant of the defensive strategy, take actions to ensure the survival of the enterprise and wait for new opportunities to emerge in the market.

\section{Literature}

1. CzajKowsKa A. 2014. Zastosowanie analizy SWOT do wskazania strategii działania wybranego przedsiębiorstwa produkcyjnego [in:] II. Techniki zarządzania przedsiębiorstwem. Wybrane zagadnienia produkcji i zarządzania w przemyśle, co-authored study edited by Anna Konstanciak Edyta Kardas, Wydawnictwo Wydziału Inżynierii Produkcji i Technologii Materiałów Politechniki Częstochowskiej.

2. Czubala A., Jonas A., Smoleń T., Wiktor J. 2004.Marketing usług. , Oficyna Ekonomiczna, Kraków.

3. INGALDI M., JAGUSIAK-KocIK M. 2013.SWOT Analysis of the Process Improvement in the Company Producing Electric Sockets. [w:] Toyotarity. Evoluation and Processes'/Products' Improvement. Monograph. Ed. Borkowski S., Ingaldi M. Aeternitas Publishing House. Alba Iulia. Romania 2013. s.72-82.

4. INGALDI M., LESTYÁNSZKA ŠKŮRKOVÁ K. 2014. Company strategy determination in food company using SWOT method. Acta Technologica Agriculturae 3, Nitra, Slovaca Universitas Agriculturae Nitriae, 2014, Vol. 17. Iss. 3, pp. 66-69

5. KosIŃSKA E.2008.Marketing międzynarodowy Zarys problematyki., Polskie Wydawnictwo Ekonomiczne, Warsaw 2008

6. LAKE N. 2005. Planowanie strategiczne w firmie. Gliwice: Wydawnictwo Helion.

7. OвŁÓJ K. 2010. Pasja i dyscyplina strategii. Jak z marzeń i decyzji zbudować sukces firmy. Warszawa : Wydawnictwo Poltext.

8. OBŁóJ K. 2001. Strategia organizacji, PWE, Warszawa, p. 182.
9. RomAnOwSKa M. 2004. Planowanie strategiczne w przedsiębiorstwie, PWE, Warsaw, p. 79.

10.ŻABIŃSKI L. (red.) 2000. Analiza strategiczna przedsiębiorstwa na potrzeby wyboru strategii rozwoju (za pomocą metody SWOT). Katowice: Wydawnictwo Akademii Ekonomicznej w Katowicach. 